\title{
LIFESTYLE MIGRATION IN THE KESZTHELY DISTRICT OF THE WEST-BALATON REGION
}

\author{
Zsuzsanna LŐKE ${ }^{a}$, Ernő KOVÁCS ${ }^{a}$, Zsuzsanna BACSI ${ }^{a}$, Gabriella \\ BÁNHEGYI ${ }^{a}$
}

${ }^{a}$ University of Pannonia Georgikon Faculty, Department of Economics, Social Sciences and Rural Development, Keszthely, Deák Ferenc str. 16.8360-Hungary email: loke@georgikon.hu

Cite this article: Lőke, Z., Kovács, E., Bacsi, Z., Bánhegyi, G. (2020). Lifestyle Migration in the Keszthely District of the West-Balaton Region. Deturope, 12(1), 4-21.

\begin{abstract}
A relatively small but growing group of migrants nowadays are people moving to countries that are better known as migrant-sending locations. These voluntary migrants - frequently retired persons - decide on moving mostly in the hope of a better life quality they think to find abroad rather than in their own country. The property purchase of foreigners therefore related to this kind of migration, and relatively little attention is being paid to this kind of voluntary, lifestyle migration, though it can have a significant economic and social impact on the host country. Foreign property owners and several persons who are in contact with these foreigners were in-depth interviewed - as the special subject require empirical research methods - in the framework of the present research to determine the main motivations of property purchases in the Keszthely District of the West-Balaton Region, Hungary. Main motivating factors were identified as economic reasons, expectancy for a better, calmer new way of living and favourable climate conditions. Following the change of regime in Hungary three era in property purchase can be differentiated in the examined region based on the direction of migration with a gap between the first and second phase after the 2008 crisis.
\end{abstract}

Key words: lifestyle migration, resident tourism, foreign citizen, property purchase

\section{INTRODUCTION}

\section{Transnational flows}

Transnational flows are getting significant and extensive in our days and compared to earlier migration situations; they represent new function and extent. For this reason, transnational flows cannot be analysed with regular methods; they rather subvert the traditional and open the way to a new paradigm. While migration typically rises from poorly developed, low-income regions and targets the more developed regions, foreign property owners usually arrive from higher-income regions to the lower-income areas. Purposes can vary - might be settling down, e.g. in the case of retired persons, they can find the lower-income region attractive with its favourable climate and environment, or still active people hold a job that can be pursued from abroad. Another purpose of property acquisition can be to own a second home (summer house) for people who don't want to give up their homes but spend significant time in the chosen other 
country. They sometimes wish to spend this considerable time away from home because they prefer the climate conditions offered by their second home. The majority of foreign owners use the house (apartment) for own purposes, but it also occurs that they rent it out for a period (Croucher, 2012).

In our research, we studied the actors (property purchasers) who represent this new kind of migration, and at the same time, create a new - not yet studied and revealed - co-existence model by dispensing their cultural values in Hungary.

It will be important to pay attention to this new flow so that we can identify the major reasons behind changing residency. This new type of migration targets countries with desired climate -in Europe Spain, Greece and Portugal or France are very popular destinations, especially the Mediterranean coastline and islands. A further popular target is the CentralEastern European region, including Hungary. Although favourable climate conditions can be experienced here only temporarily throughout the year, respondents still emphasized its importance along with their economic considerations. Since the middle of the ' 90 s people from Austria and Germany are moving to Hungary especially after Hungary joined to the NATO, then the European Union. The introduction of the Schengen zone also contributed to the sense of security. More and more foreigners invest into Hungarian undertakings, create new ones or buy properties just for the sake of holidays (Kovács et al., 2004).

\section{The definition and phenomena of lifestyle migration, motivations of moving to abroad}

The international literature describes migration generally as a hard, painful period for the migrants who even after settling down battle with feelings of vulnerability, exclusion and difficulty in inclusion. Labels such as lifestyle migration, amenity migration international retirement migration, residential tourism, on the contrary, offer a much more positive meaning of migration.

Lifestyle migration can be described as residential or amenity tourism as future settlers usually get to know the target area during their touristic travels. Their experiences of an idyllic lifestyle can be a strong motivation when deciding about creating a new home abroad and buying a suitable property for that purpose. Settlers with this motivation wish to continue the favoured way of living in their everyday life in their own property.

Recent researches focusing on this type of transnational flows conclude that there is a very definite north-south direction in lifestyle migration, which is the exact opposite of the generally experienced migration trends (Torkington, 2011, Ibrahim \& Tremblay, 2017, Rainer, 2019). The most popular routes in the case of the British are Spain, Portugal and Italy while the 
Americans choose Mexico or Panama. The Germans and the Swedish also favour Spain and Portugal, the French move to Morocco, and the Canadians choose Central or South America. Similar trends can be detected in Asia, e.g., the Japanese settling down in Thailand or in Malaysia. Major motivation factors are the favourable climate, low prices and friendly locals (Croucher, 2012). People like them usually adapt well to their new community, become a welcomed member, take part in the everyday life of the community, but at the same time search for the company of other international dwellers, making friends of other foreign origin citizens. Anglo-Saxon settlers - as usually there are people in the community who speak English - are less motivated to learn the language of the host country, often live in a cultural bubble, and don't make close contact with the local culture (Croucher, 2012).

Lifestyle immigrants have a relatively higher-level income and change their residency temporarily or permanently in the hope of a hard to define notion of better way of living (Torkington, 2011).

Buying real estate abroad happens with the intention of settling down in a foreign country and is not related to an increasingly impossible or undesirable living in their home country, much more to an expected, more comfortable, more prosperous lifestyle abroad. There are several forms of lifestyle migration, such as the so-called permanent tourism (people from developed northern, western countries moving to the Mediterranean coastal countries looking for a warmer climate and a less stressed life) (Benson \& O'Reilly, 2009). Lifestyle migration is becoming a characteristic feature and an ever-growing form of transnational flows. Although according to the popular opinion, lifestyle migrants are high-level income pensioners, many of them are school-age children or elderly widowers who seek cheaper cost-of-living (Benson \& O’Reilly, 2009).

\section{Table 1 The main characteristics of lifestyle migration}

\begin{tabular}{|l|}
\hline Lifestyle migrants leave their former homes in the hope of finding a better life quality \\
\hline Contrary to the migration of refugees, or economic refugees, lifestyle migrants deliberately search for a different \\
lifestyle, mostly to avoid the stressful way of life in modern developed countries and to ensure self-realization \\
in a better life. Livelihood and survival are not characteristic reasons. \\
\hline Lifestyle migration is the spatial mobility of relatively higher income persons with the purpose of creating a \\
new balance between work and leisure they also mediate toward the locals. \\
\hline $\begin{array}{l}\text { It can be an escape from the old monotone home routine, from the feeling of being in a trap. It also equally can } \\
\text { arise from the desire to create a new destiny with self-expression and self-actualization. Although there is the } \\
\text { goal of a more relaxed lifestyle, several of these lifestyle migrants start working in their new residence but with } \\
\text { a greater autonomy and in a less rushed way. Many start working as entrepreneurs; some can even return for a } \\
\text { while to their home country and moving back to their new home after accumulating a certain amount of money. }\end{array}$
\end{tabular}

Source: Benson \& O`Reilly, 2009 


\section{The international pensioner-migration}

Moving to a different country is getting popular among pensioners. Reaching pensioner age often accompanies other individual, family, and social circumstances that encourage the change of residency. This phenomenon was recognized first in Western societies and became widespread during time. Relocation gives an opportunity to pursue a financially sound and longer life during retirement years and at the same time to find a 'leisure-oriented disposition to move in pleasant surroundings that are well endowed with both recreational and service resources. (Rowles \& Watkins, 1993). In Europe retirement migration is especially peculiar to the British. Flanagan (2014) quotes a World Bank Report according to which 7-8 \% of the UK population live abroad and according to the Office for National Statistics in 2017 about 340 thousand UK state pension recipients lived in other EU countries - excluding Ireland (State Pension Administrative Data, Department for Work and Pension, 2020)

The deeper motivations behind the international retirement migration are not easy to determine as these are often hidden by the individual characteristics of pensioners or of the host region. Several authors however identified the favourable climate as one of the most important pull (Rodriguez et al., 1998, 2004), while further determining factors are economical, such as the difference in the cost of living in the states of the U.S. (Rodriguez, Fernandez-Mayoralas, \& Rojo, 2004).

American settlers are primarily motivated by the climate and living costs, but another recognized factor reported is the immigration encouraging policy of the Mexican and Panamanian governments (visa, taxation, property acquisition rules) (Dixon et al., 2006). Another research established economic concerns to be the most important determining factors when Americans decide on moving to a different country: lower costs of living, cheaper real estate purchase price and maintenance costs, lower property taxes, cheaper staff for running the household chores - all can be attractive especially for pensioner migrants (Croucher, 2009), Dixon et al. (2006) found that lower middle class fresh pensioners think about moving South (e.g. to Mexico) as an escape from the high and ever growing costs of medical care and medicines, from the falling purchasing power of pension, and increasing costs of transport and communication. With their moving they hope to maintain a middle-class style of living. Among economic considerations the beneficial investment into residential property in frequented touristic zones should also be mentioned (Benson \& O'Reilly, 2009). For foreign immigrants the relatively cheap investment cost might result in a good return when the property can be sold even after full renovation. After such a transaction their social mobility can significantly improve (Bantam-Masum, 2011). Most often retired migrants live from their pension disbursed 
by their country of origin and maintain their existence in their new home country. We can see quite frequently this in Spain and France where retired British and Swedish citizens enjoy their idle years (Benson \& O'Reilly, 2009). Sometimes only one of the spouses, couples is retired while the other pursue an online remote work from their new home - e.g. for a firm in Great Britain (BiE, 2011).

\section{The impact of lifestyle and retirement migration on local citizens}

Voluntary lifestyle migrants have a far more positive approach towards locals and work diligently on their integration than migrants forced by circumstances (circumstantial migrants) who have to move into a new country upon the decision of their families, therefore relate to their new environment rather negatively and their relationship with locals is more ambivalent (Torkington, 2011).

International retirement migration has a definite influence on the economic situation of the host region which can be detected in the income level of the region, in the creation of new jobs, in the real estate market and in the utilization of general services. The impact on local market conditions usually implies an increased consumption level and higher local taxes. At the same time, however, as they have larger income, many times they are the ones who can provide job opportunities to locals (housemaid, cook, gardener, contractor) (Croucher, 2012). Unfortunately, sometimes this employment takes place in the black market and equals with illegal employment with its many dark corners as Kovács et al. (2003) highlighted it in their Balaton region research concerning transnational flows. To mention some disadvantages of the retirement migration it should be noted that they don't pay health and/or social contributions and of course property tax after an owned home is lower compared to what tourists pay in the form of tourist taxes and rent. Property prices can climb much higher when the foreign buyer power is present which of course is disadvantageous for local buyers who can be driven out from the real estate market (Croucher, 2012). Retired migrants require frequent access to medical and cultural services due to their demographic and social characteristics and tend to time their claim for medical services in the host country during their chosen season, such as Canadians do in Florida (Rodriguez, Fernandez-Mayoralas, \& Rojo, 2004).

Not only migrants look forward to their new life. The arrival of new buyers usually brings a real estate market boom (Bantman-Masum, 2011). Local enterprises, agencies also expect much from residential tourism since it creates demand in the market of second homes, attracts foreign real estate investments. However, there is still a relatively small number of literatures 
concerning the analysis of the possible inherent negative environmental, social and cultural consequences.

\section{Foreign property owners in Hungary between 2001-2008}

According to the research during 2001-2002 in Hungary, in the Balaton Highlands, the main motives for property purchase of foreigners were the Hungarian origin, a former tourism experience and a Hungarian spouse/partner (Illés \& Michalkó, 2008). Foreigners preferred county seats but also towns and villages offering a "pleasant" environment and tourism resources. Among the settlements the ones in the West-Balaton region/Keszthely district were highly favoured followed by other settlements around the Balaton which proves that tourism was the main drive behind the property purchases (Illés \& Michalkó, 2003). The same was reported by Michalkó and Rácz in 2010, namely that beside the Balaton-Highlands foreigners purchased properties in settlements with spa resorts. The territorial distribution of purchased property showed a very typical pattern influenced by the nationality of the new property owners. Germans preferred settlements in the Balaton region. Also, geographical distance is a determining factor (Michalkó \& Rátz, 2010). The most sought city was the capital (Budapest) then came the towns with more frequented tourism - such as the settlements in the West Balaton Region.

\section{MATERIAL AND METHOD}

To reveal the motivation behind lifestyle migration and foreign property purchase, to learn about the (new) lifestyle of lifestyle migrants were the main purposes of this research. For the primary analysis, we chose a direct form of qualitative researches: individual in-depth interviews were conducted with foreign property owners and with the most important stakeholders, who have a day-to-day relationship with the owners. For this qualitative research a relatively small sample is enough, however, conducting and data analysis can be time consuming. In the framework of the primary research, 10 in-depth interviews were conducted with 13 persons - in three cases foreign property owner couples were interviewed who all answered the questions.

Our research was in Hungary, in the West Balaton region, in Keszthely district. We targeted both settlements on the shore of the lake and further ones inland. From the 30 settlements of the district, we finally chose two beach-side towns (Keszthely and Gyenesdiás) and five smaller 
“inland” village (Gétye, Karmacs, Alsópáhok, Nemesbük, Zalaszántó) as representatives of the district.

Among foreign property owners we conducted in-depth interviews with a German, an English and a Belgian couple, as well as with German, Ukrainian and Danish single property owners (all men). To get a clearer picture of the presence of foreign property owners we also focused on conducting in-depth interviews with several important stakeholders who are familiar and are in daily contact with such persons. In this context a real estate agent from Keszthely, the Mayor of Gyenesdiás, the Notary of the local government of Keszthely and the President of the Keszthely District Court also was asked to take part in in-depth interviews.

\section{RESULTS}

\section{Foreign property owners in the Keszthely District - interview analysis}

Summarizing our conclusions, we can say that property owners enjoy living here, they did not regret the decision to purchase their property and think they successfully integrated to the local community. The success of course partly is the result of the positive attitude of the local people, institutions and service providers. This approach isn't surprising in a region where foreign tourists are present since the 1960's along with foreign people's property purchases since the 1980's. In the beginning property purchase for foreigners was possible only through establishing an undertaking but later they were able to do that as private persons, as well. The presence of foreigners is a common feature in several settlements of the district, in Keszthely 298 and in Gyenesdiás 450 property in foreign ownership can be counted.

\section{Different eras of foreign property purchases and the motivation behind them since the change of regime}

In this chapter we share the results of the interviews conducted with the mayor, notary and realtor, and with the Ukraine respondent who is an active realtor and tourist at the same time. We chose our mayor respondent to be the mayor of Gyenesdiás because this settlement became the target of Russian and Ukrainian property purchase in such an extent that it got the label of 'being a threat to national security'. This "invasion" has passed now, but every $7^{\text {th }}$ inhabitant of this larger village of less than 4000 is now a foreign citizen.

The Capital 99 Real Estate Agency was established in 1996 with the intention to meet German customers' needs and has primarily foreign clients even today.

During the '90s mainly German-speaking people arrived at the West-Balaton region who were attracted by the proximity of Keszthely and even more of Hévíz. Even from Germany the 
first to come were people who had some attachment to Hungary. Most of them belonged to the elderly generation seeking healing who bought properties in Hévíz and its vicinity. The major reasons behind their decision were the Lake of Hévíz itself, as well as the closeness to the Lake Balaton, the pleasant countryside and the Mediterranean climate. Of course, price was also a strong motivation as many of them couldn't buy a property (they rented their homes) but here they could have their own houses/homes along with a more favourable living cost. Till the end of 1995 - in the area concerned - as it was ranked as a priority resort area at national level, foreigner was prohibited of purchasing property unless they operated an undertaking. Understandably many made use of this regulation.

Starting from 1996 citizens of the European Union could purchase property as individuals in Hévíz, Keszthely, Gyenesdiás, Vonyarcvashely, etc., except for arable land, other agricultural land, while the purchase of historic buildings required authorization. "All this means that practically there is no street in Gyenesdiás without foreign inhabitants. What is more there are streets in the village where the vast majority of houses were built by foreign citizens. Occasionally these people built houses on the neighbouring plots as well to prevent the arrival of undesirable neighbours" told us the Mayor of Gyenesdiás. "Later Germans remembering with nostalgy of Hungary gained courage and started coming to the country, mainly from the area of the former GDR. There were people from around Leipzig and Berlin looking for cheaper properties and finally moving to rural settlements farer from the Lake where they bought farmhouses which they restored and renovated. It also should be mentioned that until 2004 Germans certainly expected property prices to increase manifold with the accession of Hungary to the European Union. They built their hopes on the experience they gained concerning the real estate market in Spain where an acquired property in 6-8 years could be sold for such an increased price that the former owners became able to buy a nice family house in Hungary. So, there was a time period when many Germans arrived to Hungary from Spain. Where property prices peaked there and they sold their apartments or houses there, they could buy from that money much higher quality properties here".

Change came in the second part of the 2000's. Partially as a result of the "Merkel-program" - Germans should spend their money in their homeland - the property purchases of Germans declined. Of course there are other factors playing role in the fall of foreigners' property purchase; the expected strong property price-rise never happened after the EU accession of the country; the children and heirs of the elderly property owners were not interested in their parents' Hungarian houses, so finally many of these were put up for sale. Another factor is that until the retired owners were healthy and active, they gladly lived in Hungary but once they 
became more dependent on healthcare and recognized the shortcomings of the Hungarian health system, they decided on moving back to Germany.

In 2008, during the crisis, German property buyers disappeared entirely, and there was a long pause until property purchases started again, however this time by the English and Russians who came just in time to get the real estate agencies through the crisis years. The regional Fly Balaton Airport in the Keszthely district near the village of Sármellék played an important role, through its increased airdrome traffic, in the arrival of English and Irish property purchasers. In those two or three years during the Ryanair operated regular flights to and back from London, several properties were sold to British customers.

After 2010 another increase in property purchases took place in the West Balaton Region where the city leaders of Hévíz implemented their strategy of attracting Russians into the area. 'And when they arrived some of them chose Gyenesdiás'. According to the legislation citizens outside of the European Union can purchase property in Hungary only if the responsible government agency of the capital or the counties with territorial jurisdiction issues a permission. Permission can be issued upon the request of the potential buyer and is subject to charges. The government agency inspects if the purchase harms the interests of the local government. It means that the agency asks for the opinion of the mayor of the municipality, and checks, through the Office of Immigration and Nationality and the National Police Headquarter, if there is an entry ban, permanent ban, or arrest warrant was issued against the applicant. The permission is not necessary if the buyer is the citizen of the EU, Switzerland, Norway, Lichtenstein, Iceland, or has dual citizenship containing a Hungarian, or acquires the property by succession.

Thanks to the permit procedure, mayors of the settlements have a clear picture of the property purchase of foreigners. In the case of Gyenesdiás with cheaper properties but in the close vicinity of the town of Hévíz, during the first part of the 2010's the purchase power was felt like an invasion. The Russians and Ukrainians were interested mainly in Hévíz (not the Lake Balaton); therefore acquired real estate there and around the town. The majority of the Russian and some Ukrainian property purchasers bought larger properties, apartments as an investment, and they are engaged in renting out rooms. Others bought the property for themselves as a second home, some of them escaping the unfriendly weather conditions in their home country - e.g., if they lived in the northern parts of Russia, where the cold climate has such a bad impact on their health that they can retire at age 55. These "environmental refugees' take pleasure in spending their pensioner years as residents in a spa town. However, as the Rubel depreciated significantly leading to a high inflation due to the sanctions introduced against Russia after the occupation of the Crimean Peninsula, Russian buyers left the property 
market even if they kept their saving in USD. Probably the difficulty of obtaining the D Visa (necessary if the applicant plans to spend more than 3 months in the country) also contributed to the fall in purchase. By 2017 Russian and Ukrainian property purchases for personal/private use basically ceased almost completely. Business investments do happen even today, e.g. a guest houses, and hotels are built in Hévíz by Russian investors.

Three-four years ago German buyers returned to the property the market of the West Balaton Region. The Germans of today prefer city environment with good infrastructure, shopping options and services (e.g. hairdresser). They hope that property purchase will prove to be a good investment in the long run and at the same time wish to spend some time here. One of the motivations is saving money by living in Hungary as it is much cheaper to buy property here and services also are available for a lower price. "They want to live well here, at the Balaton. $\mathrm{He} / \mathrm{she}$ might had a small apartment in Germany and since property prices climbed high there and home loan sold for cheap, it seems to be a good move to sell it and buy a much larger, much nicer house around a beautiful lake. From selling a small flat in Munich or another city they can receive enough money to buy a nice detached house in Hungary and still saving a few hundred thousand euros which together with the pension covers the cost of living abundantly"

Concerning the age of the purchasers and their connection with the country these people come from, we surveyed the following answers: 'We don't see younger people coming (to purchase property), from Western Europe we hardly meet customers who are younger than 50. The only exception is those younger than 50 people who have a special attachment to Hungary.' 'Hungary can be attractive for those who have a good or fair pension, sold something or saved some money, maybe rented their former homes and now finally can buy their own houses. So, typically the elderly generation comes, the younger, unfortunately, doesn't.' The age distribution shows that mainly middle age and older people came and come to Hungary. 'Younger people don't buy property in this area'. In the case of third-country immigrants from the East, the picture is slightly is different: the Russians are frequently in their active age when purchasing their properties while German buyers are typically pensioners.

\section{The motivation behind buying property - according to the foreign property owners}

We had some presumptions concerning the motivations of property purchases such as having relatives in Hungary, lower cost of living, earlier tourism experience, the attractiveness of the famous spas in the region, which leads to investment into property around them. The in-depth interview results are shared in a time sequence of the property purchases. 
Our Danish respondent explained his decision about moving to Hungary with both emotional and economic reasons: 'It was in 1986. That was a very difficult and grey period in Denmark with inflation, unemployment and I just could not find my place at home. Even back then you could feel that there was a greater openness in Hungary than for example in the Soviet Union, as if the socialism operated in a different way. Moving to a socialist country was a provoking, exciting thought'. They bought their property in 1990 after they were convinced that they made a good choice, they lived in a good and beautiful place. 'If I go up to the garden I am still awestruck when I have a look at the castle of Rezi, or at the Stupa in Zalaszántó, or just watching the hills of Keszthely. You just can stay in your own garden while watching all of these, it is something to be praised. The property is in my full ownership, you can check it in the Land Registry. The fact that it is mine is a very becoming thing, and therefore I would like to stay here".

All of the German respondents mentioned the economic motivation as the most important factor in their decisions (from their pension they can finance a higher standard of living compared to Germany, and were able to have a property in their proprietorship), while the favourable environment played a secondary but also important role.

The German man who purchased his home in the region in 1997 did not hesitate when stated 'property and life is cheaper here than in Germany. 'The village I live in is a very quiet one. And the whole country is beautiful'.

The German couple who arrived from Hamburg bought a plot of land in Gyenesdiás in 1999, then built a house and moved in in 2000. Formerly they lived in a rented flat in Hamburg and they would have liked living in their own home in their old age. They savings weren't enough for buying a home in Germany, so they chose Hungary. They mentioned three reasons that fuelled the decision: 1 . They wanted to live near water as they used to, so they chose a settlement near the Balaton. 2. They preferred a quieter, more family type surroundings than in Hamburg where the air is polluted. Here they can have a much peaceful and healthier environment and still they can easily access to shopping, theatre, concerts in Keszthely or other cultural programs. 3. They find that village people around them are friendly, people are helpful and not only in the village but in the agencies, shops as well. Hungarian around them are hospitable. 4. The beautiful landscape with modadnocks, vineyards, spas and the view of Northern shore of the Balaton adds another level to feeling content.

The Belgian couple spent rather short time in Belgium as because of the husband's job they travelled a lot and spent considerable time in different countries of Africa, in Israel, even in the Soviet Union. As retirement drew closer, they felt that Belgium did not offer that kind of 
peacefulness, liberty, green area, security, climate and those conservative values which they confess. Their original plan was to move to Spain, but on the proposal of an acquaintance they decided to visit Hungary. During a few days stay they were convinced that this would be the place they want to live their life in the future, so they bought their house in the village of Nemesbük. They enjoy the beautiful landscape and mention that 'the plots of land a big, you can cultivate your own garden and neighbours are helpful'.

Family relationship as motivation was found only in the case of a Ukrainian who mentioned his wife's Hungarian relative as one but not determining reason for their moving and property purchase. They bought their first property in the Eastern part of Hungary in 2006 to ensure better living and better environment for their children. As he speaks fluent Hungarian - and worked as an interpreter in an industrial company, his command of two languages was to their benefit: "I received this job opportunity 5 years ago and it was a real escape-forward". Thus, they bought their second property in Alsópáhok, in 2014. According to him 'it is a very liveable, good and quiet place. There is everything and everything is close to us".

The English couple bought their property in Gétye, in 2016 and they soon moved here from England to live in Hungary. They mentioned that they liked that "the space of life is calmer, slower here". According to them England now is crowded with people and their own area changed a lot for the worse. Life here is much calmer, not so stressful and they find Hungary a safe country. The area they live provides much space, there is no crowd but there is peacefulness and quiet, no heavy traffic. There is also an economic consideration: as they have many animals which they transported to Hungary from England (horses, donkeys, dogs and cats) they appreciate very much that veterinary care cost less money here.

It is evident that there is a powerful need for feeling safe as safety leads to a more pleasant and less stressful life. The general description of our region contains words such as "safety" and "quiet". The English couple added "less stressful" which they applied when compared their new home with their former residence and the unfavourable changes that took place in England. During the interview with the real estate agent we learned that public security, safety of the settlement is a very important criteria when foreigners choose their property. Before making decision, they want to be sure that settlement provides a place where they can live in safety and feel safe.

Regarding the question about visitors arriving to their places or planning inviting them all respondents answered in the affirmative. Either they already welcome their friends or plan that after finishing renovation they will regularly invite some. None of them offer commercial accommodations. 


\section{Consumer satisfaction with services among the lifestyle migrants}

The respondents formulated an overall positive opinion concerning the level of services in Hungary. The highest average of satisfaction levels measured on a 1-5 evaluative scale goes for the Mayor's Offices (5.0). The respondents used words as "helpful”, "friendly" when talking about offices and the leaders of the settlements. According to the English couple the level of public services is much higher here in the rural Hungary than it was in their former rural home, where they lacked public lighting, and paved roads while payed a rather high local tax (equalled about 70 thousand HUF) at the same time.

The second highest score was given to schools, but it is important to note that the 4.66 average is the result of only three answers (Fig. 1). The others, due to their age, have no contact with schools, therefore, they did not respond. It is interesting that while dental service got a very good (4.6) score, medical care received a much lower value of (4.0). According to the Belgian couple, 'it depends on who you met. There is a fantastic rheumatologist (would give a 5) but we also met a very rude doctor who told us to learn first Hungarian and then we can get an appointment. So, we chose going to Belgium to have certain medical examinations performed'.

Figure 1 Average satisfaction with services among the foreign property owners

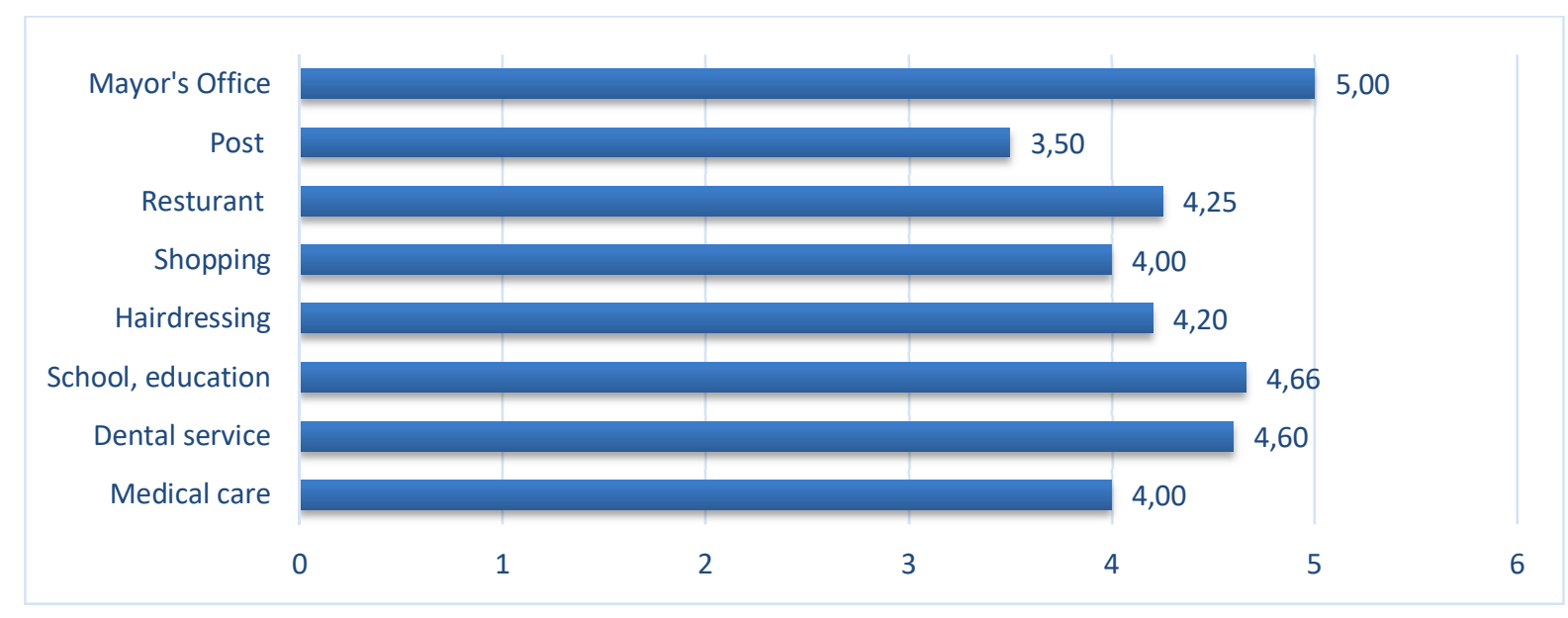

Source: own data

Hairdressing reached a good 4.2 average; restaurants got a 4.25. As for shops and vendors (and basically shop assistants) average satisfaction was only 4 . The explanation revealed that this service often lacks helpfulness, and our respondents frequently meets genuine disregard. The 
lowest average was calculated concerning postal services and the main factor is that some respondents live in villages without a post office.

We asked the owners about the things they would change in the settlements they live in. The things they mentioned were generally minor matters such as enlarging the waiting room in the local doctor's office, paving the parking lot close to the Balaton, eliminating bumps and cracks on the road. Only the respondent for Denmark spoke differently as he told the biggest kindness toward myself is to have a good time. If there is a conflict it should be handled on the spot and not waiting until it solved otherwise. And there is the saying about being rather envied than pitied. That is my attitude'. There is one thing he would change: 'I would be happy to get rid of all shiftiness in people".

According to the Belgian couple sometimes it is difficult talking with Hungarians as they tend to complain without real reason. 'Many don't enjoy their own lives and it affects their relationship with others'...' if they knew about the challenges and problems Western Europe about which they think about as a wonderland - faces they would be utterly happy with living in Hungary. Hungary should be advertised more abroad, and tourism should be strengthened and developed'.

\section{Further empirical experience regarding the foreign owners in the West Balaton Region}

The president of the District Court met foreign property owners first in the ' 90 s who were victims of burglaries. He says that every year there are some criminal proceedings when foreign property owners appear in court usually as victims of theft, burglary, fraud or deception. He also meets foreign property owners during civil proceedings concerning e.g. neighbouring rights, ownership or possession rights, claims for damages (such as against the contractor). The only occasions where foreign owners were accused persons were drunk-driving cases, as foreigners can find out too late that the Hungarian zero tolerance principle deviates significantly from the much more lenient German regulation.

As Croucher (2012) we also found that people moving to abroad as lifestyle migrants integrate well into the local community, they are welcomed immigrants who take part in the everyday life of the community with pleasure.

Our presumption that foreign property owners seek the company of other foreigners and gladly make friends with them proved to be right only in $60 \%$.

Our Danish respondent though does not seek the company of other foreigners is held in respect in his church, in the tuba quartet he plays, and in the presidency of the co-operative where he is a member. The Ukrainian respondent regularly meets Russian tourists while 
working and does not strain after keeping in touch with foreigners in his spare time. The English couple knows about the group of English people living in the neighbourhood, but they did not contact them yet. They have some foreigner friends whom they talk frequently but don't socialize with them too much. The Belgians keep contact with several foreigners and are members in some organizations (two of them are group of foreign citizens). The German couple also keep in touch with other foreigners and are members of the Tourism Association of Gyenesdiás since its establishment. The other German respondent weekly meets other foreigners for a conversation but is not member in any organizations.

\section{SUMMARY AND CONCLUSIONS}

Foreign property owners arrive from the opposite direction compared to the general transnational flows. This migration leaves regions with higher income level and targets lower income areas. One of the reasons of people leaving behind their homeland is the desire for a better climate, hence the flow in Europe toward the Mediterranean coastal line. Another target area is the Central and Eastern European region including Hungary where favourable climate is available only temporarily throughout the year, still many foreigners decide to move here since 1990. While migration is a painful act for those who are forced to leave their homes, this opposite direction of flows of lifestyle migrants offers a positive outcome. Lifestyle migrants usually have relatively higher income level, and with moving abroad, they wish to create a more comfortable living and a higher level of wellbeing.

Our goal with this present research was to evaluate the direction and the factors stimulating this small volume but in the long run probably very important transnational flow in the Keszthely District of the West Balaton Region. As this topic requires empirical investigation, we chose to conclude in-depth interviews with foreign property owners and with different actors who have frequent contact with them.

While according to the study carried out in Hungary in the Balaton Highlands between 20012002 the main reasons of foreigners purchasing Hungarian property were either a Hungarian origin, a former tourism experience, or a Hungarian spouse (partner) (Illés \& Michalkó, 2008), we found now in the Keszthely District of the West Balaton Region that a quiet, peaceful environment offering a less stressful life and the favourable climate conditions were mentioned the most frequently. The present findings are consistent with the conclusions of Kovács et al. (2004) concerning the Balaton region. In their 2004 research they summarized that "among the 
motivation factors of the sales agreement's recreational aspects (quiet, peacefulness, relaxation, pleasant landscape) play a particular role and favourable price range is also a major point".

Foreigners purchasing property in Hungary, in the West Balaton Regions are stimulated by the following factors: The main goal is to live well, the pension lifestyle migrants receive from their country of origin makes it possible for them to pursue a higher standard of living. We also identified what Benson and O'Reilly (2009) found, namely that these people escape from their former stressful life and wish to find a tranquil and peaceful way of living by moving, which is supported also by the pleasant climate and favourable environmental characteristics. And beside these, in this present research we identified a new element: the safety awareness which compounded by the other factors suggest a better life quality for lifestyle migrants.

However, our findings are different in the case of Eastern Europeans (Russians and Ukrainians) who purchase a property here. Their purpose with real estate acquisition is different, only some of them wish to use it as a second home during their pensioner years, while others see property purchase as a way to obtain the long-stay visa which can be used for moving inside the EU territory. These buyers characteristically are engaged in economic activities. A further distinctive characteristic is that property purchasers arriving from Eastern Europe prefers to have these around or in Hévíz, the famous spa town.

Both the Western European and Eastern European citizens hope that their purchase proves to be a good investment in the long run, which anticipation led them to choose property in the settlements of the West Balaton Region which is part of the Balaton Priority Recreational Area.

Concerning the country of origin, the foreign property purchasers arrived from, three era can be distinguished.

1. The period from the time of the regime change in $1989 / 1990$ till the crisis year of 2008 , when mainly Western Europeans - primarily from Germany and Austria - arrived to Hungary according to several authors - Illés and Michalkó (2003), Kovács et al. (2004), Michalkó and Rácz (2010). In 2008 with the disappearance of German buyers the real estate market paused until 2010 .

2. From 2010 Irish and English customers start arriving from Western Europe and as a new phenomenon Russians and Ukrainians start purchasing property in the region, while Germans seem to be staying away from the regional Hungarian real estate market. The Russian purchase power even caused some alarms in the area for a while as they bought many houses or started building them. 
3. Since 2017 Germans returned to the property market in the district and Russians are also here though their purchases are just a fraction now of what was characteristic a few years ago.

The age distribution of property owners shows that the typical Western European buyer belongs to the elderly age group - they are usually after retirement. Only among the Russian and Ukrainian property owners, we found that the active age group is represented to some extent. As for the relationship between the foreign newcomers and the local Hungarian population, we found that there is some interdependency. A substantial number of the local citizens depend on the foreign property owners, supply services and sell products to them. Several Hungarians look to the Germans as examples with a pleasant lifestyle and a new approach to spare time activities. In another context, however, locals and lifestyle migrants can be competitors, such as in the case of tourism, rental of rooms and spaces as many of the newcomers - though not any of our respondents - take part with a considerable advantage thanks to their foreign contacts.

\section{Acknowledgement}

We acknowledge the financial support of Széchenyi 2020 under the EFOP 3.6.1-16-2016-00015 project on the comprehensive institutions building for facilitating smart specialization in the University of Pannonia, through its sub-program T30 on Foreign Property Owners in the Keszthely District.

\section{REFERENCES}

Bantam-Masum, E. (2011). You Need to Come Here to See What Living is Really About: American Expatriation in Merida, Mexico. Miranda, No. 5. URL: http://miranda.revues.org/2494 Accessed: 22 June 2018

Benson, M., \& O'Reilly, K. (2009). Lifestyle Migration: Expectations, Aspirations and Experiences; Ashgate: Farnham

BiE (2017). Case Studies of British citizens living on the European continent. British in Europe - The Coalition of UK Citizens in Europe. Accessed: 10 April 2017

Croucher, S. (2009). The Other Side of the Fence: American Migrants in Mexico. University of Texas Press: Austin, TX, USA

Croucher, S. (2012). Privileged Mobility in an Age of Globality. Societies, 2, 1-13. doi:10.3390/soc2010001

Dixon, D., Murray, J., Gelatt, J., \& Papademetriou, D. (2006). America's Emigrants. US Retirement Migration to Mexico and Panama. The Migration Policy Institute. https://www.migrationpolicy.org/research/reports Accessed: 14 Jan 2018

Flanagan, Oz (2014). How Many British immigrants are there in other countries?.Online paper at: https://www.statslife.org.uk/social-sciences/1910-how-many-british-immigrantsare-there-in-other-people-s-countries, posted on 18 Nov 2014, Accessed: 20 March 2018

Ibrahim, Z. \& Tramblay, E. (2017). Lifestyle Migration and the Quest for a Life-long Vacation. Tourisme résidentiel, 36(2) https://journals.openedition.org/teoros/3074_Accessed: 20. March, 2020 
Illés, S., \& Michalkó, G. (2003). A turizmus és a migráció néhány összefüggése Magyarországon. Demográfia, 46(4), 352-374.

Illés, S., \& Michalkó, G. (2008). Relationships between International Tourism and Migration in Hungary: Tourism Flows and Foreign Property Ownership. Tourism Geographies, 10(1), 98-118. DOI: 10.1080/14616680701825271

Kovács, E., Csite, A., Oláh, M., \& Bokor, I.: (2004) Sziget a magyar tengeren: külföldi ingatlantulajdonosok a Balatonnál. Szociológiai Szemle, 3, 79-107.

Kovács, E., Bokor, I., Filebics, M., \& Lőke, Z. (2003). Transznacionális áramlások hatásai a Balaton Kiemelt Üdülõkörzetben - különös tekintettel az Európai Unió állampolgáraira és a magyarországi roma kisebbségekre OKTK kutatás (kódszám 002) zárótanulmány, Keszthely, Magyarország.

Michalkó, G., \& Rátz, T. (2010). Hungarian spa destinations in the tourism-oriented property market. Hungarian Geographical Bulletin, 59(2), 131-146.

Rainer, G. (2019). Amenity/lifestyle migration to the Global South: Driving forces and sociospatial implications in Latin America. Third World Quarterly, 40(7), 1359-1377, DOI: $10.1080 / 01436597.2019 .1587291$

Office for National Statistics: State Pension Administrative Data, Department for Work and Pension, https://www.ons.gov.uk/economy/investmentspensionsandtrusts/articles/pensionersint heeuanduk/2017-09-05 Accessed: 10. March, 2020

Rodriguez, V., Fernandez-Mayoralas, G., \& Rojo-Pérez, F. (1998). European Retirees on the Costa del Sol: A Cross-National Comparison. International Journal of Population Georgraphy, 4, 183-200.

Rodriguez, V., Fernandez-Mayoralas, G., \& Rojo Pérez, F. (2004). International Retirement Migration: Retired Europeans Living on the Costa Del Sol, Spain. Population Review, 43(1), 1-36. January 2004. DOI: 10.1353/prv.2004.0009

Rowles, G. D., \& Watkins, J. F. (1993). Elderly migration and development in small communities. Growth and Change, 24(3), 511. - quoted by. in: Rodriguez, V., Fernandez-Mayoralas, G., \& Rojo Pérez, F. (2004). International Retirement Migration: Retired Europeans Living on the Costa Del Sol, Spain. Population Review, 43(1), 1-36. January 2004. DOI: 10.1353/prv.2004.0009

Torkington, K. M. (2011). The discursive construction of place-identity: British lifestyle migrants in the Algarve. $\mathrm{PhD}$ Thesis, Lancaster University, Lancaster 